\title{
401 集水装置を有する軸流水車に関する研究 Study on Axial Flow Hydraulic Turbine with Collection Device
}

\author{
○ 大久保 薰（茨城大院） 岩本 浩信（茨城製作所）正 西 泰行（茨城大） \\ 正 稲垣 照美（茨城大）菊池 伯夫（茨城製作所） \\ Kaoru OKUBO, Graduate School of Ibaraki University, Ibaraki, Japan \\ Hironobu IWAMOTO, Ibasei, Ltd., Ibaraki, Japan \\ Yasuyuki NISHI, Ibaraki University, Ibaraki, Japan \\ Terumi INAGAKI, Ibaraki University, Ibaraki, Japan \\ Norio KIKUCHI, Ibasei, Ltd. , Ibaraki, Japan
}

\begin{abstract}
A hydraulic turbine for an open channel can generate power at low head and doesn't affect the environment because it doesn't have incidental equipment. However, because the rotational speed is low, the hydraulic turbine outer diameter becomes large. Therefore, an axial flow hydraulic turbine with collection device, using kinetic energy of open channel flow, is proposed. The performance and flow field of impeller only, collection device only and combination of impeller and collection device were clarified. It was checked the speed increasing of collection flow in collection device by analysis result of collection device only and analysis result of output of combination of impeller and collection device is larger than analysis result of impeller only.
\end{abstract}

Key Words: Hydraulic Turbine, Runner, Collection Device, Performance, Flow field

\section{1. 粕票}

近年，環境問題やエネルギ一問題が顕在化し，自然エネ ルギーの有効利用が求められている．中でも水力エネルギ 一は,他の自然エネルギーと比べてエネルギー密度が高く, 比較的変動が少ないため, 安定してエネルギーが得られる。

水力発電に使用される水車林，大きく分けて管路用水車 と開水路用水車に分類される。管路用水車はダムや水槽等 に水を貯め, 落差 (位置エネルギ一) を利用して導水する. しかしながら，発電設備の建設適地が減少しているため, 今後の増設が困難とされている。一方，開水路用水車は尊 水するための付帯設備が不要で, 比較的低落差での発電が 可能である。しかし，発電設備索現地に固定化するので， 依然設置場所は限定される。

そこで，落差を利用せず，開水路流れの運動エネルギー を利用し，集水增速させることで出力向上を図った可搬式 の開水路用水車を提案する。本水車は軸流羽根車に高さ方 向一定のディフューザ部を持つ集水装置を付加した構造で ある。本研究では，この特殊な集水装置を有する軸流水車 の開発を目的として，数值解析により羽根車単体及び集水 装置単体の性能特性と流れ場を明らかにするとともに，こ れらを組み合わせた場合についても検討した。

\section{2. 数值解析方法及ひ率件}

本研究で用いた羽根車の概略を図 1 に，4 種類の集水装 置(C.D.)の概略を図 2(a)〜 (d)に，両者を組み合わせた水車 の概略を図 3 に示す.集水装置はディフューザ部を固定し， ノズル及びつばの有無を変化させている．その全長 $x$ は は, ノズルの無いType A る。また, Type C は $100 \mathrm{~mm}$, Type D は $200 \mathrm{~mm}$ の高さのつ ばを集水装置出口に設けている。なお，ディフューザは高 さ方向 $(z$ 方向)一定で, 横方向 $(y$ 方向)に拡大しており, 広 がり角はいずれも80である。

数值解析には沉用熱流体解析コード ANSYS CFX13.0 用い, 三次元定常流れ解析を行った.作動流体は水であり， 乱流モデルはSST モデルを使用した。羽根車と集水装置 (Type D)を組み合わせた計算モデルを図 4 に示す。境界条 件として，入口境界に無限遠方の速度 $v_{\infty}=1.5 \mathrm{~m} / \mathrm{s}$, 羽根車に
回転速度，出口境界にダージ圧力 $0 \mathrm{~Pa}$ の条件を与えた。計 算格子数は羽根車単体の解析で約 117 万要素，集水装置単 体の解析で約 130 万要素前後，両者を組名合わせた場合の 解析で約 182 万要素である.

\begin{tabular}{|c|c|}
\hline 入力係数: $C_{i}=\psi K^{3}\left(I-v^{2}\right)$ & 出力: $W[\mathrm{~W}]$ \\
\hline 圧力倸数: $C_{p}=\left(P-P_{x}\right) /\left(\rho v_{\infty}^{2} / 2\right)$ & 周速比: $\lambda_{i=r_{f}(0) / v_{\infty}}$ \\
\hline 背圧係数: $C_{p h}=\left(P_{3}-P_{x}\right) /\left(\rho v_{x}{ }^{2} / 2\right)$ & ハブ比: $v=r_{h} / r_{r}$ \\
\hline 圧力回復係数: $C_{p d}=\left(P_{3} P_{2}\right) /\left(\rho v_{1}^{2} / 2\right)$ & 流体密度: $\rho\left[\mathrm{kg} / \mathrm{m}^{3}\right]$ \\
\hline 出力係数: $C_{W}=W /\left(\rho \pi r_{r}^{2} v_{v_{3}}^{3} / 2\right)$ & 負荷係数: $\psi=\left(P_{1}-P_{2}\right) /\left(\rho v_{1}^{2} / 2\right)$ \\
\hline 増速比: $K=v_{1} / v_{\infty}$ & 回転角速度: $\omega[\mathrm{rad} / \mathrm{s}]$ \\
\hline 静压: $P[\mathrm{~Pa}]$ & 添え字 \\
\hline 羽根車八ブ半径: $r_{h}[\mathrm{~m}]$ & 1, 2:羽根車直前, 羽根車直後 \\
\hline 羽根車チップ半径 $r_{i}[\mathrm{~m}]$ & 3:集水装置出口 \\
\hline 䋓坟速度. $y[\mathrm{~m} / \mathrm{s}]$ & 钮限遠方 \\
\hline
\end{tabular}

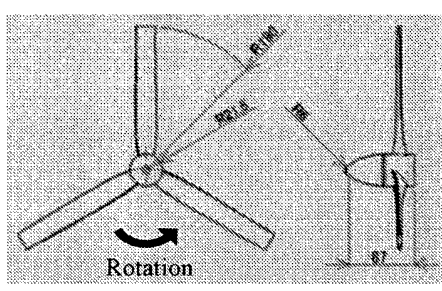

Fig.1 Runner

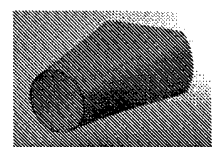

(a) Type A

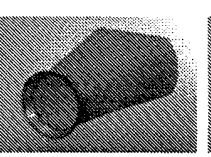

(b) Type B

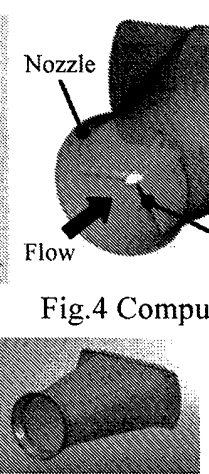

(c) Type C
Fig.2 Collection device

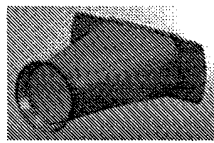

(d) Type D

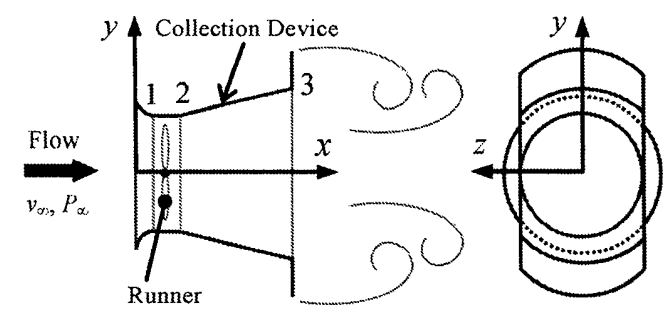

Fig.3 Hydraulic turbine 


\section{3. 解析結果及び考察}

各集水装置単体の増速比 $v / v_{\infty}$ の $x$ 方向分布を図 5 に，各 集水装置単体の性能を表 1 に示す。ここで， $v$ は各 $x$ 方向 位置での流量平均值を用いており, $v_{1}$ は Type Aが $x / x_{\Gamma}=0.0$, Type B〜D が $x / x_{\Gamma}=0.08$ でのvに対応する，ノズル及びつば の無い Type A 孝みると, 集水装置出口より入口の $v / v_{m}$ が大 きく，増速比 $K$ は 1.331 になっている。したがって，ディ フューザによる増速効果が得られていることがわかる。

Type A と Type B を比較すると, Type B は背圧係数 $C_{p b}$ が やや増加するものの，圧力回復係数 $C_{p d}$ が大幅に增加する ため, Type B の $K$ は Type Aに対して約 1.47 倍に增大して いる。これは，ディフューザ入口にノズルを付加したこと により，水の滑らかな流れ远みを実現したためと考えられ る(1). Type B, Type C 及び Type D を比較すると， $C_{p d}$ はい ずれもほぼ同一である。しかし， $C_{p b}$ はつばの大きい Type D が最も低く, Type Dの $C_{p b}$ はつばの無い Type B の約 3.26 倍に低下している。これに対応して Type D $の K$ は 2.248 と最も大きく, Тype B のそれの約 1.15 倍に增大しているこ とがわかる。これは，つばにより集水装置出口の圧力が低 下し，その領域よりさらにディフューザ部入口の圧力が低 下するためであり，集水装置周囲とディフューザ部入口と の圧力差が增大し, 集水增速されているもの上考えられる。

Type B 及び Type D の压力分布在 6(a), (b)に示本. Type $\mathrm{D}$ はつばの影響で出口の圧力が大きく低下し，そのディフ ューザ入口付近の圧力は, Type Bより大きく低下している ことが確認される。

羽根車単体及び羽根車と集水装置(Type D)の組み合わせ の周速比 $\lambda$ と出力係数 $C_{W}$ の関係図 7 に示す。羽根車単 体の $C_{W}$ の最大值は， $\lambda=4.25$ のとき 0.253 である。一方，羽 根車と集水装置の組み合わせの $C_{W}$ の最大值は， $\lambda=5.95 \sigma$ とき 0.765 である。したがって，羽根車に集水装置を付加 すると, $C_{W}$ の最大值は高周速比側に移行し, 羽根車単体の 約 3.02 倍に向上することがわかる。これは，図 8 に示す増 速比 $K$ と入の関係より，羽根車と集水装置の組み合わせで は, $\lambda=5.95$ のとき $K$ が羽根車単体の約 1.43 倍に増大するた めである。ただし，集水装置単体と比較して，羽根車と集 水装置の組み合わせの $K$ は, 後述の翼負荷の影響で大幅に 低下しており，之の増加とともにさらに低下する。このこ とについて，以下に検討する。

増速比 $K$ は $K=v_{1} / v_{\infty}=\left\{\left(1-C_{p b}\right) /\left(1-f C_{p d}+\psi\right)\right\}^{0.5}$ で表される ${ }^{(2)}$. ここで, $f$ は羽根車出口の旋回流れや集水装置の入口損失 等を考慮した修正係数で， $\psi$ 沬羽根車の翼負荷に関する負 荷係数である. 図 9 に示す $C_{p d}$ と $\lambda$ の関係より, 羽根車と 集水装置の組み合わせの $C_{p d}$ は高周速比側で高くなってお り, $\lambda=5.95$ において集水装置単体より向上している。一方, 図 10 に示す $C_{p b}$ と $\lambda$ の関係より, 羽根車と集水装置の組み 合わせ $C_{p b}$ は高周速比側で高く， $\lambda=5.95$ において集水装 置単体より高くなっている。したがって, $f=1, \psi=0$ と仮定 して $\lambda=5.95$ における $C_{p d}$ と $C_{p b}$ を代入すると $K=3.01$ となり， 羽根車と集水装置を組み合わせた場合の集水装置単体とし ての $K$ は, 集水装置単体 $(K=2.248)$ よりも向上していると考 えられる。

しかしながら，実際は図 11 に示すように，羽根車出口の 旋回流れや集水装置の入口損失等により， $\lambda=5.95$ のとき $f=0.962$ である。来た，図 12 に示すように羽根車と集水装 置の組み合わせの $\psi$ は，羽根車単体よりも増大し， $\lambda=5.95$ のとき $\psi=0.899$ となる．特にこの $\psi$ の影響が大きく，羽根 車と集水装置を組み合わせると, $\lambda=5.95$ のとき $K=1.19$ とな り，K惟水装置単体よりも低下することがわかる。

以上のことから，羽根車に集水装置を付加すると，羽根 車の翼負荷の影響で集水装置単体の増速比は大幅に低下寸
るものの，增速比及び負荷係数が羽根車単体よりも増大す るため，出力係数は大幅に向上するといえる.

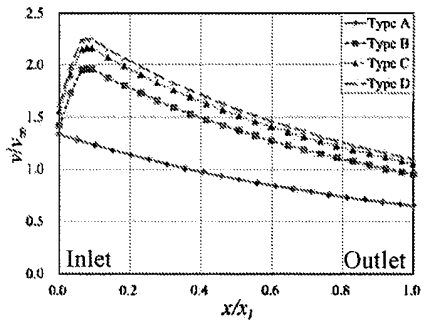

Table.1 Collection device performance

Fig. 5 Velocity ratio distribution

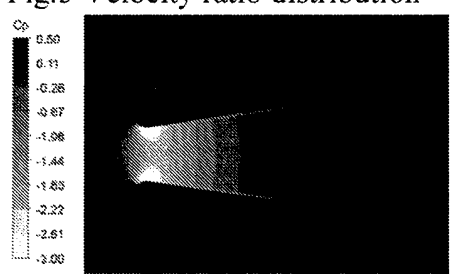

(a) Type B

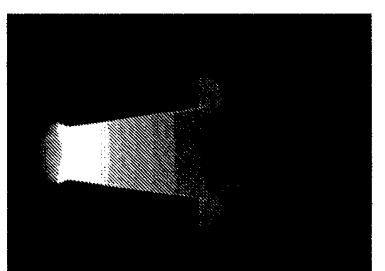

(b) Type D

\begin{tabular}{|l|c|c|c|}
\multicolumn{4}{c}{ performance } \\
\hline & $C_{p d}$ & $C_{p b}$ & $K$ \\
\hline Type A & 0.357 & -0.292 & 1.331 \\
\hline Type B & 0.742 & -0.188 & 1.960 \\
\hline Type C & 0.743 & -0.485 & 2.162 \\
\hline Type D & 0.742 & -0.612 & 2.248 \\
\hline
\end{tabular}

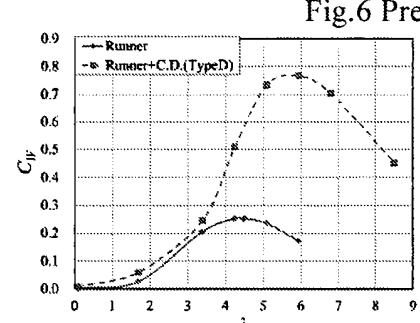

Fig. 7 Power coefficient

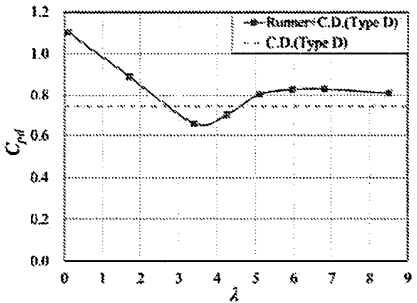

Fig.9 Pressure recovery coefficient

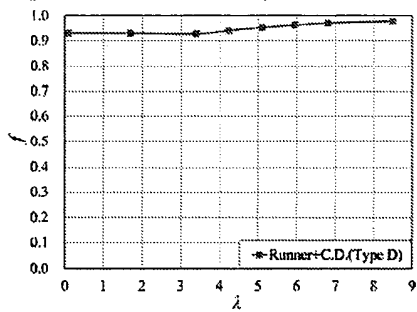

Fig.11 Modified coefficient

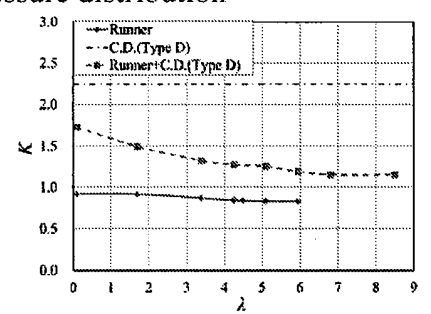

Fig. 8 Velocity ratio

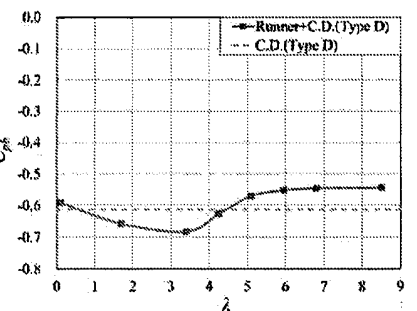

Fig. 10 Back pressure coefficient

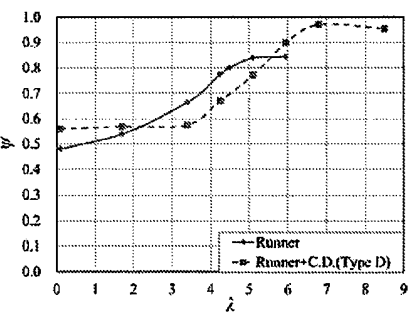

Fig. 12 Loading coefficient

\section{4. 結曹}

（1）集水装置性能はノズル及び大きなつばを持つ Type D が最も良く，単体で増速比 2.25 を実現したが, 羽根車 と組み合わせると増速比は大幅に低下し, 周速比の増 加とともにさらに低下する。

（2）羽根車に集水装置を付加すると，羽根車の翼負荷の影 響で集水装置単体の増速比は大幅に低下するものの， 増速比及び負荷係数が羽根車単体よりも增大寸るた め, 出力係数は羽根車単体の約 3 倍に向上する.

\section{䊅考文献}

（1）大屋裕二・他 2 名, 日本航空宇宙学会論文集, Vol.50, NO.587, 2002, pp.477-482.

（2）井上雅弘・他 2 名，ターボ機械，Vol.30, No.8, 2002, pp.497-502. 